\author{
D. Sadyk, M.Y. Hyun \\ KIMEP University, Kazakhstan, Almaty, \\ e-mail: dina.sadyk@kimep.kz
}

\title{
MODAL ANTECEDENTS OF SOCIAL MEDIA USAGE MOTIVATIONS FOR GENERATION Z IN KAZAKHSTAN
}

The phenomenon of social media and consequent transformations of our life and work represent a research interest in the area of people's online behavior, which increasingly impacts marketing science and practice. Prior studies investigated motivational factors of social media usage. This research aims to reveal these factors' antecedents such as different online content formats or virtual experience types. The study's output contributes to the enhancement of social media theory. The sample includes 103 KIMEP University's bachelor students as representatives of generation Z in Kazakhstan. Factor analysis and structural equation modeling were performed to process the data with the application of SPSS 19.0 and WarpPLS 6.0 programs. Based on the research's results we suggest three modal antecedents including verbal-based, pictorial-based, and animated-based virtual experience types, which affect socializing, entertainment and self-status seeking motivations to use social media. Application of the specific online content formats to the particular social media gratification is supposed to improve the effectiveness and efficiency of elaboration and implementation of consumer communication programs and customer relationship strategy in achieving marketing and sales targets.

Key words: generation $Z$, media richness, social media usage motivations, virtual experience, modal antecedents.

\author{
А. Садык, М.Й. Хюн \\ КИМЭП Университеті, Қазақстан, Алматы қ., \\ e-mail: dina.sadyk@kimep.kz \\ Қазақстанда Z буыны үшін \\ әлеуметтік желілерді қолдануды \\ ынталандыратын модальді антецеденттер
}

Әлеуметтік медианың феномені біздің өміріміз бен іс-әрекетіміздің өзгеруіне ықпал етеді. Бұл процестер маркетинг саласындағы ғылым мен практикаға көбірек әсер ететін ғаламтордағы алам мінез-құлқы саласындағы зерттеушілерді қызықтырады. А^дыңғы ғылыми еңбектер әлеуметтік медианы пайдаланудың мотивациялық факторларын зерттеді. Бұл зерттеудің мақсаты - интернеттегі мазмұнның әртүрлі форматтары немесе виртуалды тәжірибенің түрлері сияқты осы факторлардың антецеденттерін анықтау. Осы зерттеудің нәтижелері әлеуметтік медиа теориясының дамуына үлес қосады. Осы зерттеудің іріктемесі Қазақстандағы Z ұрпағының өкі^дері ретінде КИМЭП Университетінің 103 студентін қамтиды. SPSS 19.0 және WarpPLS 6.0 көмегімен деректерді өңдеу үшін факторлық та^дау және құрылымдық теңдеуді модельдеу әдістері қолданы^ды. Ұсынылған зерттеудің нәтижелері бойынша виртуалды тәжірибенің вербальды, графикалық және анимациялық түрлеріне негізделген үш модальді антецеденттер ұсынылған. Бұл модальді антецеденттер әлеуметтену, ойын-сауық және тәуелсіз мәртебені іздеу сияқты әлеуметтік медианы пайдаланудың мотивациялық факторларына әсер етеді. Әлеуметтік медианы қолданудың белгілі бір себептері бойынша онлайн мазмұнының нақты форматтарын пайдаяану тұтынушылармен байланыс бағдарламаларын жасау мен іске асырудың тиімділігі мен тиімділігін арттыруға, сондай-ақ маркетинг пен сату мақсаттарына қол жеткізуде тұтынушылармен қарым-қатынас стратегиясын жасауға ықпал ететін болады деп болжанады.

Түйін сөздер: Z ұрпағы, медиа мүмкіндіктер теориясы, әлеуметтік медианы пайдалану мотивациясы, виртуалды тәжірибе, модальды антецеденттер. 


\title{
А. Садык, М.Й. Хюн \\ Унивеситет КИМЭП, Казахстан, г. А^маты, \\ e-mail: dina.sadyk@kimep.kz \\ Модальные антецеденты мотиваций использования \\ социальных сетей \\ А^я поколения Z в Казахстане
}

\begin{abstract}
Феномен социальных медиа способствует трансформационным переменам в нашей жизни и деятельности. Эти процессы представляют интерес Аля исследователей в области человеческого поведения в режиме онлайн, которое все больше влияет на науку и практику в области маркетинга. В предшествующих научных работах были изучены мотивационные факторы использования социальных медиа. Целью Аанного исследования является выявление антецедентов этих факторов, таких как разнообразные форматы онлайн контента или типы виртуального опыта. Результаты этого исслеАования представляют собой вклаА в развитие теории социальных медиа. Выборка данного исследования включает 103 студента бакалавриата Университета КИМЭП в качестве представителей поколения Z в Казахстане. Методы факторного анализа и моделирования структурными уравнениями были использованы Аля обработки Аанных с помощью программ SPSS 19.0 и WarpPLS 6.0. Основываясь на результатах представленного исследования, мы предлагаем три модальных антецедента на основе вербального, изобразительного и анимационного типов виртуального опыта. Эти модальные антецеденты влияют на такие мотивационные факторы использования социальных медиа, как социализация, развлечение и поиск самостоятельного статуса. Предполагается, что применение конкретных форматов онлайн-контента Аля определенных причин использования социальных медиа может способствовать улучшению эффективности и результативности разработки и внедрения программ коммуникаций с потребителями, а также стратегии взаимоотношений с потребителями в достижении целей по маркетингу и продажам.
\end{abstract}

Кмючевые слова: поколение Z, теория богатства медиавозможностей, мотивации использования социальных медиа, виртуальный опыт, модальные антецеденты.

\section{Introduction}

Active social media (SM) users' number grew on $23 \%$ to 7.14 million this year in Kazakhstan, which is in line with the trend in the world, where the number of SM users increased on $9 \%$ to 2.48 billion people for the same year (Kemp, 2019: 221). Despite the impressive rise of the SM usage figure, SM penetration in Kazakhstan is still lower (38.5\%) than the average worldwide indicator of $45 \%$, while the penetration indicator is more than $70 \%$ in 15 countries (Kemp, 2019: 221). Based on the above data, it could be supposed that swiftly evolving SM still have a big potential for further saturation in Kazakhstan.

However, there is an insufficient number of statistics and scientific papers regarding SM users' behavior in the country. For example, regarding motivations to use SM, available data show three main types of SM activities in Kazakhstan including comments of others posts $(24.81 \%)$, search and acquiring new people $(21.9 \%)$, and discussions (12.44\%) in 2018 (zakon.kz, 2019: 1). These activities reflect the only socializing motivation of people to use SM while existing studies suggest several factors, which we apply to test motivations of SM usage in Kazakhstan.
Furthermore, our scientific interest extends to the exploration of a new avenue for SM theory in terms of a differential effect of various modal antecedents on SM usage motivations. Knowledge of these associations not only contributes to the extension of SM theory but also gives marketers additional tools for planning consumer communications and related activities in SM in more productive ways. Prediction of consumer behavior in SM may help to manage the consumer buying decision process with a higher output. The actuality of the problem is based on the fact that $39 \%$ of people in Kazakhstan consider advertising in SM the most effective, as reported by the Elim Institute of marketing and sociological researches in 2018.

We ground the research on uses and gratification and media richness theories to build a framework for the investigation of forming consumers' motivations to use SM based on people's needs and preferences in various virtual experience forms. The study focuses on $\mathrm{Z}$ generation in Kazakhstan as the biggest age group among SM users in the country, e.g. young people aged from 18 to 29 mostly represent user's base in the biggest country's SM platform VKontakte (67\%), also in Instagram (62\%) and Facebook (54\%) (Irgaliyev, 2017: 1). Factor analysis and structural equation modeling were used 
as statistical methods in this study in order to define a model of associations of modal antecedents with SM usage motivations. The main purpose of this study is to extend the current theoretical background of SM usage since there is a limited number of global quantitative papers and scarce local statistics data.

\section{Literature review}

\section{The role of social media}

One of the most used extant definitions of SM is suggested by Kaplan and Haenlein (Kaplan, 2010: 10) as "a group of Internet-based applications that build on the ideological and technological foundations of Web 2.0, and that allow the creation and exchange of User Generated Content" (p. 61). Contemporary online technologies give people opportunities to consume and generate information simultaneously, whilst exchanging various contents with each other in different formats, mostly for free of charge. Easy access, affordability, and availability provide favorable conditions for rapid growth and further development of SM in the world.

There are many spreading online forms of SM such as social networks (e.g., Facebook or VKonakte), business networks (e.g., LinkedIn), video sharing platforms (e.g., YouTube), photo sharing site (e.g., Pinterest), and many other examples. The phenomenon of SM, conditioned by technological innovations and its development, leads to inevitable changes in consumer behavior, and consequent adoption of new ways of customer relationship management by businesses, or in other words "digital transformation of marketing" (Lamberton, 2016: 146). So, companies should thoroughly elaborate on an explicit strategy for the active involvement of their customers in SM, which noticeably extends opportunities to hear voices of customers, and even impact their discussions (Bruhn, 2012: 21). Also, SM has been granting additional powerful channel for brand communications with a component consumer engagement as Gomez et al. (Gomez, 2018: 11) stated that "social media brand engagement explains $63.6 \%$ and social media brand relationship quality $48.9 \%$ of Facebook followers' intention" (p. 19). Moreover, some studies explored a decisive role of recommendations of other consumers rather than opinion leaders in online purchases, indicating that companies need to encourage users to share their feedback about their offers in SM influencing purchasing by other consumers in the future (Forbes, 2013: 107). Overall, it is noted that "for executives, social media platforms can facilitate business transformation in terms of managing customer relationships, brand assets, and business processes" (Luo, 2013: 146).

\section{Grounded Theories}

The role of mass communications has been increasing in marketing science during SM evolution when marketers should know not only individual customer psychological needs but also socio-psychological gratifications due to the social character of SM, which reflects one of the main differences of contemporary digital marketing from traditional marketing (Bruhn, 2012: 21). Uses and gratification as a social-psychological theory may explain the attraction and attachment of consumers to distinct media addressing specific users' needs (Xu, 2012: 18).

Moreover, some authors suggest uses and gratification concept as an integral part of mass communication theory for the researches of computer-mediated communications like the theory was used for investigations of traditional media such as newspaper, radio, or television for the last century (Ruggiero, 2000: 35; Xu, 2012: 18; Whiting, 2013: 8). Analysis of numerous aspects of mass communications with the application of increasingly comprehensive analytical techniques may help to answer the main question "Why do people become involved in one particular type of mediated communication or another, and what gratifications do they receive from it?" (Ruggiero, 2000: 29). The goal of our study is to contribute to answering this question employing uses and gratification theory.

The second ground theory for our research is media richness, which states that diverse media have different potential capacities in terms of complexity and number of informational cues to transmit from sender to receiver as well as the speed of getting feedback from the receiver to the sender. Russ, Draft, and Lenger (Russ, 1990: 25) named this capacity as media richness that ranges from the highest to the lowest level. Many authors consider that the main factor for media selection with the best appropriate capacity for a particular task is the ambiguity of communicated information (Daft, 1986: 18; Daft, 1981: 18; Weick, 1979: 5). For example, a more ambiguous message requires the richer medium with a higher capacity to be transferred, e.g. the medium with more sophisticated features. Media richness theory explains that correspondence between characteristics of communication medium and communication task defines the effectiveness of communication (Daft, 1984: 12). Initially, Daft and Lengel (Daft, 1986: 18) suggested the theory for corporate communications, arguing that there are two interdependent factors such as 
uncertainty and equivocality, or ambiguity, which impact information flow within organizations. The authors consider an organization as an open social system. This fact justifies the purpose of the theory application for SM researches.

\section{Contemporary researches}

Based on the analysis of attraction of virtual communities, Ridings and Gefen (Ridings, 2004: 29) suggested marketers pay special attention to social support and friendship as important factors of online network successes, in addition to information exchange as the first popular reason to join the virtual communities. More gratifications such as "pastime, affection, fashion, share problems, sociability, and social information" were proposed in the research among users of Facebook and Instant Messaging (Quan-Haase \& Young, 2010: 350). Other motives of SM usage were exposed by $\mathrm{Xu}$ et al. (Xu, 2012: 18) during their analysis of data about the usage of social networking sites among young generation representatives. The authors divided the reported motivations into two groups, utilitarian and hedonic. The former included coordination and immediate access, and the latter were affection and leisure. Assuming that SM users may simultaneously represent customer and employee, the scholars concluded that firms need to utilize their online networking platforms for both external and internal communications.

H.-F. Lin (Lin, 2006: 8) examined online consumer behavior, and defined that attitude and perceived behavioral control impact intentions of people to join virtual networks. The author adopted measurement items proposed by Taylor and Todd (Taylor, 1995: 33) for the investigation of information technology usage. All measures, except subjective norms and Internet self-efficacy, were found as statistically significant factors of people' joining online networks. It was proved that users' attitude is composed of three behavioral aspects such as perceived usefulness, ease of use, and trust; while perceived behavioral control depends on facilitating conditions or available resources.

Park, Kee, and Valenzuela (Park, 2009: 5) analyzed relationships between SM gratifications and offline political and civic activities among college students who use Facebook. In the research, despite some variations among different demographic groups, SM usage motivations such as socializing, entertainment, self-status seeking, and information seeking were tested as significant factors for all participants. Also, the authors found that information-need factor prevails in associations with civic and political actions rather than recreational gratifications. They suggested revealing Facebook usage reasons in different contexts and communities to get a deeper insight into the nature of Facebook trends and its impact on social and political events.

Analogue research compared Facebook with another online platform Pinterest regarding interrelationships between personality features, gratifications, and emotional consequences, where measures of Park et al. (Park, 2009: 5) were adapted with additional three items about inspiration, new ideas and projects within the information-seeking motivation (Lin, 2017: 9). Repeatedly, four reasons for SM usage, including socializing, entertainment, self-status seeking, and information seeking, were proved as meaningful predictors examined across two social media types. The authors recommended measuring these motivations in different countries, and go beyond the suggested list of four motivations exploring more gratifications and ways of utilization of other SM platforms.

Regarding content types, varied formats of information representation are adopted by firms to influence users of the virtual world via different human perception systems creating several types of virtual experience. Hyun, Lee, and $\mathrm{Hu}$ (Hyun, 2009: 16) suggested that "the typology of virtual experience can be explained by two dimensions: vividness and interactivity" (p. 149). Accordingly, the authors define the five types of virtual experience (VE) that range from the least vivid and interactive verbal-based VE to the most vivid and interactive animated-based VE, also vivid pictorial-based $\mathrm{VE}$ and non-interactive 3D VE that have low interactivity, and vivid interactive-based 2D/3D VE with medium interactivity.

\section{Methodology}

\section{Measures}

One of our survey's objectives is to measure existing SM usage motivational factors in Kazakhstan. So, the first research question is about the gratification of SM users' needs in the country.

RQ 1: What SM-usage motivations are in Kazakhstan?

The second research question is to reveal possible modal antecedents of SM usage motivations and create a model of these relationships.

RQ 2: What modal formats of information representation associated with distinct SM usage factors?

The measures for the research model's constructs were adapted from the extant literature, subtly modified for ensuring their appropriateness 
to social media in general rather than to the specific type of social networks like Facebook or Instagram.

Five items were employed to measure the socializing motivation, asking about social motives to use SM including getting peer support, meeting and connecting with other people, feeling belonging to a community, and talking with others (Park, 2009: 5). Three items used to measure the entertainment motivation asked whether SM are entertaining, funny, or exciting (Park, 2009: 5). Three items applied to measure the self-status seeking motivation, which asked what reasons inspire respondents to use SM such as feeling peer pressure, a desire to look cool, or a contribution to career development (Park, 2009: 5). Five items were used to measure the informationseeking motivation asking whether users need to get information about events, products, services, what's going on or to look for ideas, inspiration or plan new projects (Park, 2009: 5; Lin, 2017: 9).

Six modes of information presentation were used to measure VE asking respondents to assess a degree of their preferences during usage of SM. Audio and text were included in verbal-based VE, visual was used as a representation of pictorialbased VE, video was introduced as non-interactive $3 \mathrm{D} V \mathrm{VE}$, webinar was incorporated into interactivebased VE, and Virtual Reality (VR) was considered within animated-based VE (Hyun, 2009: 16).

All items for all constructs and VE types were measured using a seven-point Likert scale $(1=$ very low, $4=$ neutral, 7 = very high).

Before filling in the questionnaire, the students were asked three general questions. The first question was about the number of SM platforms, in which they are registered. The second one asked to disclose the number of SM platforms they use. The third question revealed how many hours per day they spent in SM.

Data collection and respondents' profiles

Data were collected using a self-administrated questionnaire in the Russian language. A reverse translation from English into Russian and then back to English was done for providing the consistency between the original English and Russian versions. 103 undergraduate volunteers of KIMEP University participated in the survey completing the questionnaire in printed form. One participant was excluded from the survey because of his negative answer about SM usage, which was considered as an outlier.

The demographic data showed that the respondents' ages range from 17 to 26 , and female dominates with 64 percent of the share of all participants. The students have different business specializations and study years. The average number of registered SM platforms is 5.18 per person, and the average number of used SM platforms is 4.11 per person. The average number of hours spent on $\mathrm{SM}$ is about 3 hours per day per person.

\section{Hypotheses}

We assume relationships between various VE types and SM usage motivations. Despite the low richness and the least vividness of Verbal-based $\mathrm{VE}$, it is still widely used by people when physical contact is impossible due to its interactive feature. This VE type can transmit the main meaning or idea of information, allow keeping relationships between people, be socially active, and even entertain with story-telling on the distance. Therefore, the first hypothesis is about the influence of verbal-based VE on SM usage motivational factors.

H1: Verbal-based VE associates with SM usage motivations

H1a: Verbal-based VE associates with socializing motivation to use SM

H1b: Verbal-based VE associates with entertainment motivation to use SM

H1c: Verbal-based VE associates with information-seeking motivation to use SM

H1d: Verbal-based VE associates with selfstatus seeking motivation to use SM

The second hypothesis regards more vivid VE, but not interactive pictorial-based VE.

$\mathrm{H} 2$ : Pictorial-based VE associates with SM usage motivations

H2a: Pictorial-based VE associates with socializing motivation to use SM

$\mathrm{H} 2 \mathrm{~b}$ : Pictorial-based VE associates with entertainment motivation to use SM

$\mathrm{H} 2 \mathrm{c}$ : Pictorial-based VE associates with information-seeking motivation to use SM

$\mathrm{H} 2 \mathrm{~d}$ : Pictorial-based VE associates with selfstatus seeking motivation to use SM

The highest media richness, interactivity, and vividness allow animated-based VE gratifying many users' needs from socializing to entertainment. It is the only VE type that can be applied if it is necessary to simulate reality. This VE is a relatively new tool for marketers for promotion and advertising. So, the third hypothesis has a high priority in this research as SM-usage motivations might be predictive by animated-based VE.

H3: Animated-based VE associates with SM usage motivations

H3a: Animated-based VE associates with socializing motivation to use SM 
H3b: Animated-based VE associates with entertainment motivation to use SM

$\mathrm{H} 3 \mathrm{c}$ : Animated-based VE associates with information-seeking motivation to use SM
H3d: Animated-based VE associates with selfstatus seeking motivation to use SM

Accordingly, Figure 1 depicts a proposed conceptual research model.

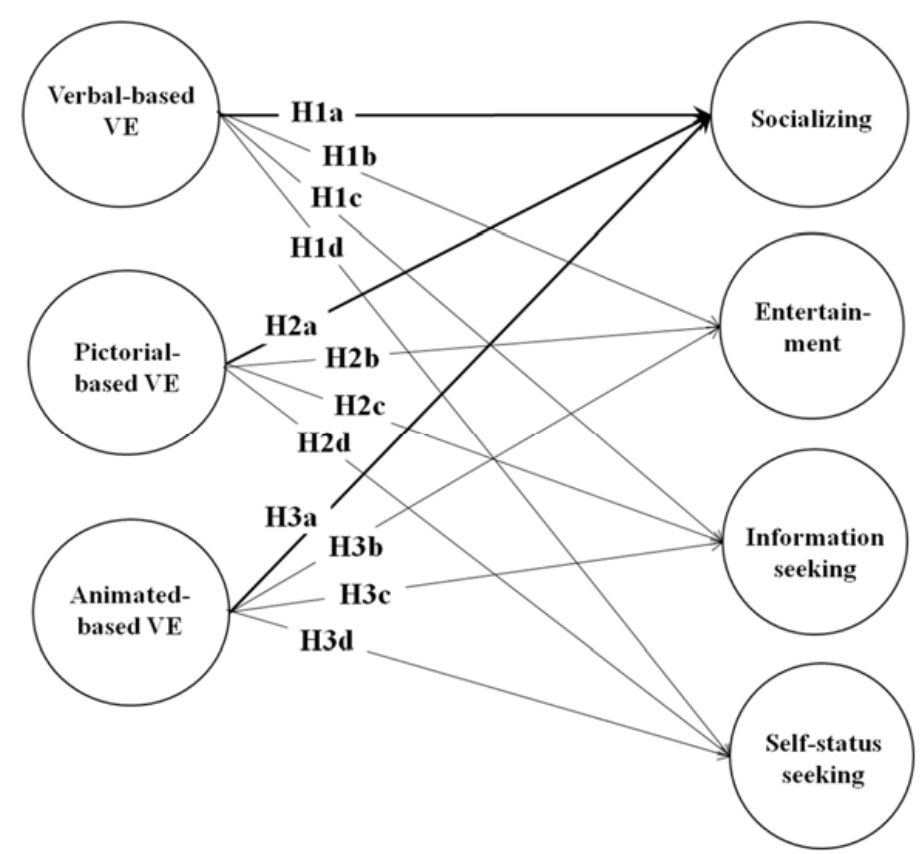

Figure 1 - The conceptual research model of relationships VE antecedents of SM usage motivations

\section{Data analysis and results}

\section{Statistical analysis}

SPSS 19.0 was used to produce descriptive statistics and to conduct an exploratory factor analysis (EFA) that evaluated the possibility of common method variance (Podsakoff, 1986: 14). Structural equation modeling (SEM) analysis was conducted using Partial Least Square (PLS), a powerful and robust tool (Henseler, 2009: 43) because of the minimal requirements for measurement scales, sample size, and residual distributions (Chin, 1998: 4). Also, as an SEM approach, PLS is well suited for testing mediation hypotheses (James, 2006: 12). Although PLS can be used to confirm the theory, it can also be used to suggest where relationships might or might not exist and propositions for further testing (Blanco, 2013: 17).

A three-step approach was used for SEM analysis that consisted of confirmatory factor analysis (CFA), a test of SEM of the research model, and a test for mediation effects. WarpPLS 6.0, a software application for graphical path modeling with latent variables, was used to perform those analyses, and bootstrapping generated the path coefficients, their standard errors, and t-statistics for testing the hypotheses (Chin, 1988: 42).

Measurement model

Before the structural model was tested, the measurement model was developed to validate the measures' properties used in this study. The measurement model was evaluated to examine the measures' reliability, convergent validity, and discriminant validity.

Reliability, which refers to the internal consistency of the indicators that measure the underlying factors, has been established as one of the essential prerequisites for construct validity (Mentzer, 1995: 20). As Garver and Mentzer (Garver, 1999: 25) recommended, both Cronbach's $\alpha$ in EFA and composite $\alpha$ in CFA should be reported. To achieve reliability, average variance extracted (AVE), which should also be reported because of a complementary measure of composite reliability (Medsker, 1994: 26), should be above 0.50 (Hair, 2009: 899), and both composite $\alpha$ (Fornell, 1981: 12) and Cronbach's $\alpha$ (Dunn, 1994: 28) should be greater than 0.70 . As shown in Table 
1, the Cronbach's $\alpha$ coefficients ranged from 0.567 to 0.855 , the composite $\alpha$ coefficients were between 0.776 and 0.913 , and the AVE of the constructs ranged from 0.515 to 0.777 . As a result, internal consistency was achieved for all constructs except self-status seeking.

Convergent validity refers to the extent to which a set of items that are assumed to represent a construct converge on the same construct (Ladhari, 2010: 14).
In line with Chin (Chin, 1988: 42), when convergent validity is achieved, the PLS indicators load much higher on their hypothesized factors than they do on other factors. One item INF1 was excluded from the information seeking factor due to low cross-loading, which was less than 0.5 . Since the loadings of all other indicators on their hypothesized factors were higher than the cross-loadings in the model (Table1), convergent validity was established.

Table 1 - Results of the CFA for the multi-dimensions of the SM usage motivations scale

\begin{tabular}{|c|c|c|c|c|}
\hline \multirow[t]{2}{*}{ Factors and items } & \multirow{2}{*}{$\begin{array}{c}\text { Convergent Validity } \\
\begin{array}{c}\text { WarpPLS Std. Loadings } \\
\text { (t-value) }\end{array} \\
\end{array}$} & \multicolumn{3}{|c|}{ Reliability } \\
\hline & & $\mathrm{C} \alpha$ & $\mathrm{CO}$ & AVE \\
\hline \multicolumn{5}{|c|}{ Socializing 0.7630 .8410 .515} \\
\hline SOC1 To get peer support from others. & \multicolumn{4}{|c|}{$0.831 * *(9.223)$} \\
\hline SOC2 To meet interesting people. & \multicolumn{4}{|c|}{$0.778 * *(9.023)$} \\
\hline SOC3 To feel some kind of belonging to a community. & \multicolumn{4}{|c|}{$0.801 * *(8.688)$} \\
\hline SOC4 To talk about something with others. & \multicolumn{4}{|c|}{$0.825 * *(9.419)$} \\
\hline SOC5 To stay in touch with people I know. & \multicolumn{4}{|c|}{$0.897 * *(7.555)$} \\
\hline \multicolumn{5}{|c|}{ Entertainment 0.8550 .9130 .777} \\
\hline ENT1 Because it is entertaining. & \multicolumn{4}{|c|}{$0.929 * *(10.918)$} \\
\hline ENT2 Because it is funny. & \multicolumn{4}{|c|}{$0.886 * *(12.391)$} \\
\hline ENT 3 Because it is exciting. & \multicolumn{4}{|c|}{$0.816^{* *}(10.517)$} \\
\hline \multicolumn{5}{|c|}{ Self-status seeking 0.5670 .7760 .549} \\
\hline STS1 Because I feel peer pressure. & \multicolumn{4}{|c|}{$0.887 * *(10.619)$} \\
\hline STS2 Because it helps myself look cool. & \multicolumn{4}{|c|}{$0.843^{* *}(10.613)$} \\
\hline STS3 To contribute to my career development. & \multicolumn{4}{|c|}{$0.798 * *(5.626)$} \\
\hline \multicolumn{5}{|c|}{ Information seeking 0.7600 .8410 .519} \\
\hline INF2 To learn about what's going on. & \multicolumn{4}{|c|}{$0.827 * *(5.962)$} \\
\hline INF3 To get useful information about products/services. & \multicolumn{4}{|c|}{$0.928 * *(9.805)$} \\
\hline INF4 To look for ideas. & \multicolumn{4}{|c|}{$0.914 * *(10.200)$} \\
\hline INF5 To look for inspiration. & \multicolumn{4}{|c|}{$0.821 * *(8.535)$} \\
\hline INF6 To plan new projects. & \multicolumn{4}{|c|}{$0.862 * *(9.272)$} \\
\hline \multicolumn{5}{|c|}{ Verbal-based VE 0.3930 .7670 .622} \\
\hline AUD Audio, including podcasts. & \multicolumn{4}{|c|}{$0.947 * *(9.850)$} \\
\hline TXT Text. & \multicolumn{4}{|c|}{$0.825 * *(9.850)$} \\
\hline Pictorial-based VE & \multicolumn{4}{|c|}{1.0001 .0001 .000} \\
\hline VIS Visual, including infographics. & \multicolumn{4}{|c|}{$1.000 * *(13.219)$} \\
\hline \multicolumn{5}{|c|}{ Animated-based VE 1.0001 .0001 .000} \\
\hline VR Virtual Reality & \multicolumn{4}{|c|}{$1.000 * *(13.219)$} \\
\hline $\begin{array}{l}\text { Note: } \mathrm{C} \alpha=\text { Cronbach's } \alpha, \mathrm{CO}=\text { composite } \alpha, \mathrm{AVE}=\text { ave } \\
.576 \text { significant at } 0.01 \text { (two-tailed test). }\end{array}$ & ariance extracted; $* \mathrm{t}=1.96$ & sign & it at 0 . & $* * \mathrm{t}=$ \\
\hline
\end{tabular}


Discriminant validity confirms that two concepts within the construct are distinct (Hair, 2009: 899). Discriminant validity estimated through a comparison of the square root of AVE for any two constructs with the correlation estimates between the two constructs (Fornell, 1981: 12). Table 2 shows discriminant validity since the square root of AVEs were bigger than the correlation coefficients between any constructs' pairs.

Multicollinearity negatively affects the results of SEM when there are high correlations $(\mathrm{R}>$ 0.80 ) among the exogenous constructs (Reisinger, 1999: 25). Since the correlation coefficients of constructs were lower than 0.80 , no violation of multicollinearity appeared.

Table 2 - Discriminant validity test

\begin{tabular}{|c|c|c|c|c|c|c|c|c|}
\hline \multirow{2}{*}{ Constructs } & \multirow{2}{*}{ AVE } & \multicolumn{5}{|c|}{ Factor Correlations } & \multirow[b]{2}{*}{ (6) } & \multirow[b]{2}{*}{ (7) } \\
\hline & & (1) & (2) & (3) & (4) & (5) & & \\
\hline (1) Socializing & 0.515 & 0.718 & & & & & & \\
\hline (2) Entertainment & 0.777 & $0.234^{*}$ & 0.882 & & & & & \\
\hline (3) Self-status seeking & 0.549 & $0.375 * *$ & $0.229 *$ & 0.741 & & & & \\
\hline (4) Information seeking & 0.519 & $0.368 * *$ & 0.144 & 0.161 & 0.720 & & & \\
\hline (5) Verbal-based VE & 0.622 & -0.019 & 0.111 & -0.145 & 0.146 & 0.789 & & \\
\hline (6) Pictorial-based VE & 1.000 & 0.151 & $0.283 * *$ & 0.012 & 0.070 & $0.417 * *$ & 1.000 & \\
\hline (7) Animated-based VE & 1.000 & $0.233^{*}$ & $0.199 *$ & $0.199 *$ & 0.128 & 0.009 & 0.050 & 1.000 \\
\hline
\end{tabular}

Note: Two-tailed test for correlations between factors: ${ }^{*} \mathrm{t}=1.960$ is significant at 0.05 ; and ${ }^{* *} \mathrm{t}=2.576$ significant at 0.01 ; Diagonal bold numbers signify the square roots of the AVEs.

\section{Hypothesis testing}

The estimated research model produced an average AVE of 0.590 , while the average $\mathrm{R}^{2}$ of the model was 0.075 as Table 3 shows. These statistics suggest that variances in the model were explained.

Since PLS path modeling lacks an index that provides the user with a global validation of the model (Vinzi, 2010: 36), a global criterion of goodness-of-fit (Tenenhaus, 2005: 47) and the effect sizes for $\mathrm{R}^{2}\left(\mathrm{f}^{2}\right)$ (Cohen, 2003:736) were adopted to validate PLS path modeling. Goodness-of-fit, defined as the geometric mean of the average communality (or AVE) and the average $\mathrm{R}^{2}$ for endogenous factors, is calculated as

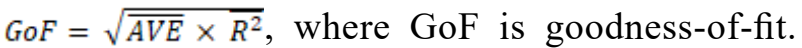
$\mathrm{f}^{2}$, proposed by Cohen et al. (Cohen, 2003: 736) is determined by $f^{2}=R^{2} \div\left(1-R^{2}\right)$. While the $\mathrm{f}^{2}$ values of $0.02,0.15$, and 0.35 are proposed as potentially useful estimates of small, medium, and large effect sizes, respectively, the goodness-offit values are suggested as $\mathrm{GoF}_{\text {small }}=0.10, \mathrm{GoF}_{\text {me- }}$ $=0.25$, and $\mathrm{GoF}_{\text {large }}=0.36$. As Table 4 shows, goodness-of-fit is 0.210 , which exceeds the cutoff value for a small effect size. The $\mathrm{f}^{2}$ value is 0.081 , which exceeds the cut-off value of 0.02 for small effect size. Therefore, it is evident that the research model performs well compared to the baseline values defined above.

Table 3 - Validation criteria for a PLS-SEM moderating model

\begin{tabular}{|c|c|c|c|c|c|c|}
\hline \multirow{2}{*}{ Indices } & \multirow{2}{*}{ Interpretation } & \multirow{2}{*}{ Size } & \multirow{2}{*}{$\begin{array}{l}\text { Recommended } \\
\text { level }\end{array}$} & Hypothesized Model & & \\
\hline & & & & Endogenous factors & $\mathrm{R}^{2}$ & AVE \\
\hline \multirow{3}{*}{$f^{2}$} & \multirow{3}{*}{ Effect of size for $\mathrm{R}^{2}$} & Small & 0.02 & Socializing & 0.081 & 0.515 \\
\hline & & Medium & 0.15 & Entertainment & 0.114 & 0.777 \\
\hline & & Large & 0.35 & Self-status seeking & 0.066 & 0.549 \\
\hline & & & & Information seeking & 0.037 & 0.519 \\
\hline
\end{tabular}


Continuation of table 3

\begin{tabular}{|c|c|c|c|c|c|c|}
\hline \multirow{2}{*}{ Indices } & \multirow{2}{*}{ Interpretation } & \multirow{2}{*}{ Size } & \multirow{2}{*}{$\begin{array}{l}\text { Recommended } \\
\text { level }\end{array}$} & \multirow{2}{*}{$\begin{array}{c}\text { Hypothesized Model } \\
\text { Endogenous factors }\end{array}$} & \multirow[b]{2}{*}{$\mathrm{R}^{2}$} & \multirow[b]{2}{*}{ AVE } \\
\hline & & & & & & \\
\hline \multirow{3}{*}{ GoF } & \multirow{3}{*}{ Goodness-of-Fit } & Small & 0.10 & & & \\
\hline & & Medium & 0.25 & & & \\
\hline & & Large & 0.36 & & & \\
\hline & & & & Average & 0.075 & 0.590 \\
\hline \multicolumn{2}{|c|}{$f^{2}=R^{2} \div\left(1-R^{2}\right)$} & $\begin{array}{l}\text { Small- } \\
\text { medium }\end{array}$ & & & \multicolumn{2}{|c|}{$f^{2}=0.081$} \\
\hline \multicolumn{2}{|c|}{$G o F=\sqrt{\overline{A V E} \times \overline{R^{2}}}$} & $\begin{array}{l}\text { Small- } \\
\text { medium }\end{array}$ & & & \multicolumn{2}{|c|}{$\mathrm{GoF}=0.210$} \\
\hline
\end{tabular}

Table 4 - Results of the hypothesized model and $\beta$ coefficients tests

\begin{tabular}{|c|c|c|c|c|c|}
\hline Hyp. & Paths & $\begin{array}{c}\beta \text { coefficients } \\
\text { (Std. error })\end{array}$ & t-value & $\begin{array}{c}\text { Effect } \\
\text { size }\end{array}$ & Test results \\
\hline H1 & Verbal-based VE $\rightarrow$ SM usage motivation & & & & Partially Supported \\
\hline H1a & Verbal-based VE $\rightarrow$ Socializing & $-0.095(0.097)$ & -0.988 & 0.002 & Not supported \\
\hline H1b & Verbal-based VE $\rightarrow$ Entertainment & $-0.006(0.099)$ & -0.057 & 0.001 & Not supported \\
\hline H1c & Verbal-based VE $\rightarrow$ Self-status seeking & $-0.179 *(0.094)$ & -1.900 & 0.026 & Supported \\
\hline H1d & Verbal-based VE $\rightarrow$ Information seeking & $0.143(0.095)$ & 1.497 & 0.021 & Not Supported \\
\hline H2 & Pictorial-based VE $\rightarrow$ SM usage motivation & & & Partially Supported \\
\hline H2a & Pictorial-based VE $\rightarrow$ Socializing & $0.179 *(0.094)$ & 1.899 & 0.027 & Supported \\
\hline H2b & Pictorial-based VE $\rightarrow$ Entertainment & $0.276^{* *}(0.092)$ & 3.004 & 0.078 & Supported \\
\hline H2c & Pictorial-based VE $\rightarrow$ Self-status seeking & $0.077(0.097)$ & 0.794 & 0.001 & Not supported \\
\hline H2d & Pictorial-based VE $\rightarrow$ Information seeking & $0.004(0.099)$ & 0.044 & 0.000 & Not supported \\
\hline H3 & Animated-based VE $\rightarrow$ SM usage motivation & & & Partially Supported \\
\hline H3a & Animated-based VE $\rightarrow$ Socializing & $0.225^{* *}(0.093)$ & 2.415 & 0.052 & Supported \\
\hline H3b & Animated-based VE $\rightarrow$ Entertainment & $0.185^{*}(0.094)$ & 1.964 & 0.037 & Supported \\
\hline H3c & Animated-based VE $\rightarrow$ Self-status seeking & $0.196^{*}(0.094)$ & 2.091 & 0.039 & Supported \\
\hline H3d & Animated-based VE $\rightarrow$ Information seeking & $0.127(0.096)$ & 1.322 & 0.016 & Not Supported \\
\hline Note: Two-tailed test for hypothesis verification: $* \mathrm{t}=1.960$ is significant at $0.05 ;$ and $* * t=2.576$ significant at 0.01. \\
\hline
\end{tabular}

Based on the received results, we suggest a model of associations between various modal antecedents and SM usage motivational factors as Figure 2 shows. Users, who seek socializing and entertainment in SM might be attracted and kept with pictorial-based and animated-based virtual experience types. Users who seek self-status gratification from SM could not be touched with verbal messages or communications but may be impressed with animated-based tools. 


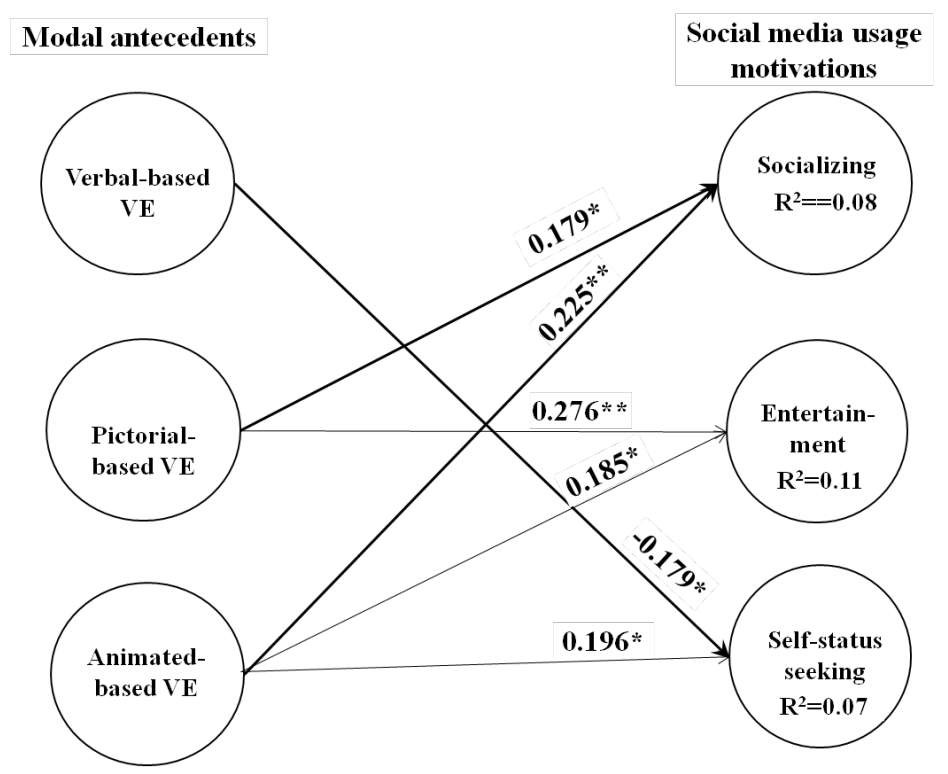

Figure 2 - The model of modal antecedents influence on SM-usage motivations

\section{Discussion}

Previous studies successfully applied the etic approach to testing SM usage motivations, including socializing, entertainment, self-status seeking, and information seeking, across various national groups (Park,2009: 5; J.-S. Lin, 2017: 9). Based on their proved positive results, we used these motivations as universal measures for our research in Kazakhstan and confirmed their significance in the local culture with a minor difference. One item of getting information about events was excluded from the information-seeking factor due to low crossloading of less than 0.5 . So, in our study, information seeking factor composed of five items that distinct from extant papers. It raises a question, whether it is conditioned by a local cultural peculiarity in general or specific attitude of a particular generation group in the country. Hence, we consider that this item about the information of events should not be excluded from the future investigations among the same generation or other generations with the objective to confirm our results and get the deeper insight into this local distinction or accept the universality of the information-seeking motivation that composed of six items. Overall, the etic-emic approach could be tested for revealing other possible cultural specific features in SM usage motivations in Kazakhstan. For that reason, an additional preliminary survey may be conducted across targeted generation groups to uncover more items and even more factors to test within the suggested model.
No prior studies about modal antecedents of SM usage motivations were found during the literature review. We used the only six modalities to represent VE types, two of which, webinar and video, were excluded from the model testing due to low crossloadings, less than 0.5 . As a result of the exclusion, three of five VE types were included in the research model. Probably, the model can be enhanced with the other two VE types if more items in terms of content formats are added to the measures. Various types of SM content, which described by many authors (Ellenring, 2019: 1; Frost, 2016: 1; O'Sullivan, 2019: 1; Sarma, 2018: 1), can be used for augmenting all VE types to test the model. For example, quizzes, contests, shareable quotes, forums or conferences may be measured within interactive 2D/3D-based VE type. And, vlogs, cinemagraph, animated infographic, VR tour or VR guide as items could be included in the potential antecedent of noninteractive 3D-based VE.

Three modal antecedents of SM usage motivations within the proposed research construct can be enhanced with the items, which represent existing and recently developed forms of content. Pictorial-based VE type may include memes, animated GIFs, quote covers, comics, cartoons, screenshots, charts or calculators. Verbal-based VE type may be complemented with quora, stories, articles, case studies, newsletters or E-books.

Lastly, we believe that value co-creation theory may reinforce the research's background to reflect the important aspect of the active participation of 
people in firms' value creation processes due to the SM phenomenon (Ramaswamy, 2016: 14; SeeTo, 2014: 8; Singaraju, 2016: 12). The augmented theory ground could contribute to the model by unveiling new SM usage factors. Some studies describe contributing and participating types of SM usage in line with other motivations encouraging scholars for deeper investigation in the area (e.g., Bolton, 2013: 23).

\section{Conclusion}

The study's results partially supported hypotheses, which suggested the relationships between modal antecedents and SM usage motivation. Based on the result, the most powerful online content format is animated-based VE that gratifies socializing, entertainment and self-status seeking motivations to use SM among generation $\mathrm{Z}$ in Kazakhstan. Pictorial-based VE positively addresses the socializing and entertainment needs of young users of SM in the country. Verbal-based VE negatively associates with self-status seeking motivation to use SM in the same target audience.

The important analytical contribution of this study is the proposed prediction model of the influence of distinct modal antecedents on specific motivations of SM usage. Marketers may practice the model to foresee the effectiveness of consumer communications about their company or brand in SM taking into consideration the differential effect of various modalities of information representation. For example, the information given in pictorial and animated modes would positively affect users who seek for socializing and entertainment gratifications in SM. Consumers seeking for self-status could be pushed away with verbal forms of communications, but be attached with animated forms of information. The latter form of modality is also attractive for communications with consumer entertainment purposes in SM.

The proposed model of relations between modal antecedents and SM usage motivations enhances SM theory in terms of deeper consumer insight. This knowledge may equip practitioners with more productive management of online content to increase customers' loyalty and generate more sales. Also, the research data augment the local statistics with the general information about the intensity of SM usage among generation $\mathrm{Z}$ in Kazakhstan, including the average number of registered and used SM platforms, and the average hours spent in SM per person. In addition to the available country's data about socializing motivation to use SM, more motivational factors such as entertainment, selfstatus seeking, and information seeking were defined for young people. Also, the research output enhances the theoretical knowledge of SM for academic and practical applications.

\section{Further research}

From a theoretical research perspective, we think that the value co-creation concept should be used in future studies in the area of SM usage because this particular type of media gives people unique opportunities to participate in the creation of new products, services, and ideas in easiest and effective ways. The value co-creation approach not only reinforces the theoretical background of the research but also can contribute to revealing additional important measures of gratifications to use SM and enhance the model of modal antecedents of SM usage motivations.

From a practical perspective, we recommend a non-student base as a sample for further studies of SM usage motivations and its modal antecedents. Also, other generation groups in addition to generation $\mathrm{Z}$ should be covered by the research. Furthermore, we propose to apply the etic-emic approach to explore possible cultural aspects of gratifications to use SM in Kazakhstan. As the current study limited to six formats of SM content for the proposed model testing, more items for VE types measures may be used to enhance existing modal antecedents within the construct as well as to add other types of modal antecedents like interactive 2D/3D-based VE and non-interactive 3D-based VE to the model. We believe that other antecedents of SM gratifications such as content duration or length and emotional modalities can be tested to assess the impact of the measures on SM usage.

\section{References}

Blanco B., Guillamon-Saorín E., Guiral A. (2013) Do non-socially responsible companies achieve legitimacy through socially responsible actions? The mediating effect of innovation // Journal of Business Ethics, vol. 117(1), pp. 67-83.

Bolton R.N. et al. (2013) Understanding Generation Y and their use of social media: a review and research agenda. Journal of Service Management, vol. 24(3), pp. 245-267. 
Bruhn M., Schoenmueller V., Schäfer D.B. Edited by Coulter K.S. (2012) Are social media replacing traditional media in terms of brand equity creation? Management Research Review, vol. 35(9), pp. 770-790.

Chin W. (1988) The partial least squares approach to structural equation modelling. In G. A. Marccoulides (Ed.), Modern methods for business research (pp. 295-336). Magwah, NJ: Lawrence Erlbaum Associates Inc.

Chin W. (1998) Issues and opinions on structural equation modeling. MIS Quarterly, vol. 22(1), pp. 7-10.

Cohen J.P., Cohen S., West G., Aiken L.S. (2003) Applied multiple regression/correlation analysis for the behavioral sciences ( $3^{\text {rd }}$ ed.). Mahwah, NJ: Lawrence Erlbaum Associates Inc.

Daft R.L., Lengel R.H. (1986) Organizational information requirements, media richness and structural design. Management Science, vol. 32(5), pp. 554-571.

Daft R.L., Macintosh N.B. (1981) A tentative exploration into the amount and equivocality of information processing in organizational work units. Administrative Science Quarterly, vol. 26(2), pp. 207-224.

Daft R.L., Weick K.E. (1984) Toward a model of organizations as interpretation systems. The Academy of Management Review, vol. 9(2), pp. 284-295.

Dunn S.C., Seaker R.F., Waller M.A. (1994) Latent variables in business logistics research: scale development and validation. Journal of Business Logistics, vol. 15(2), pp. 145-172.

Ellering N. (2019) 113 content types to organize with your marketing calendar, https://coschedule.com/blog/types-of-content/

Forbes L.P., Vespoli E.M. (2013) Does social media influence consumer buying behavior? An investigation of recommendations and purchases. Journal of Business \& Economics Research, vol. 11(2), pp. 107-112.

Fornell C., Larcker D.F. (1981) Evaluating structural equation models with unobservable variables and measurement error. Journal of Marketing Research, vol. 18, pp. 39-50.

Frost A. (2016) 7 types of awesome social media content your brand can be creating right now, https://buffer.com/resources/ social-media-content

Garver M.S., Mentzer J.T. (1999) Logistics research method: employing structural equation modeling to test for construct validity. Journal of Business Logistics, vol. 20(1), pp. 33-57.

Gómez M., Lopez C., Molina A. (2019). An integrated model of social media brand engagement. Computers in Human Behavior, vol. 96, pp. 196-206.

Hair J.F., Black W.C., Babin R.J., Anderson R.E., Tatham R.L. (2009) Multivariate data analysis (6th ed.). Upper Saddle River, New Jersey: Pearson Prentice Hall.

Henseler J., Ringle C.M., Sinkovics R.R. (2009) The use of partial least squares path modelling in international marketing. In R.R. Sinkovics, P.N. Ghauri (Eds.), New challenges to international marketing: Advanced in international marketing (pp. 277-319). Bingley: Emerald JAI Press.

Hyun M.Y., Lee S., Hu C. (2008) Mobile-mediated virtual experience in tourism: concept, typology and applications. Journal of Vacation Marketing, vol. 15(2), pp. 149-164

Irgaliyev E. (2017) Social networks in Kazakhstan: Instagram for youth, Odnoklassniki for senior citizens, https://365info. kz/2017/06/sotsialnye-seti-v-kazahstane-instagram-dlya-molodezhi-odnoklassniki-dlya-pensionerov

James L.R., Mulaik S.A., Brett J.M. (2006) A tale of two methods. Organizational Research Methods, vol. 9, pp. 233-244.

Kaplan A.M., Haenlein M. (2010) Users of the world, unite! The challenges and opportunities of social media. Business Horizons, vol. 53(1), pp. 59-68.

Kemp S. (2019) Digital 2019: Global digital overview, https://datareportal.com/reports/digital-2019-global-digital-overview

Ladhari R. (2010) Developing e-service quality scales: a literature review. Journal of Retailing and Consumer Services, vol. 17, pp. 464-477.

Lamberton C., Stephen A.T. (2016) A thematic exploration of digital, social media, and mobile marketing: research evolution from 2000 to 2015 and an agenda for future inquiry. Journal of Marketing, vol. 80(6), pp. 146-172.

Lin H.-F. (2006). Understanding behavioral intention to participate in virtual communities. CyberPsychology \& Behavior, vol. 9(5), pp. 540-547.

Lin J.-S., Lee Y.-I., Jin Y., Gilbreath B. (2017) Personality traits, motivations, and emotional consequences of social media usage. Cyberpsychology, Behavior, and Social Networking, vol. 20(10), pp. 615-623.

Luo X., Zhang J., Duan W. (2013) Social media and firm equity value. Information Systems Research, vol. 24(1), pp. 146-163.

Medsker G.J., Williams L.J., Holahan P.J. (1994) A review of current practices for evaluating causal-models in organizationalbehavior and human-resources management research. Journal of Management, vol. 20, pp. 439-464.

Mentzer J.T., Kahn K. (1995) A framework for logistics research. Journal of Business Logistics, vol. 16(1), pp. 231-250.

Named the most popular social network among Kazakhstanis, https://www.zakon.kz/4983082-nazvana-samaya-populyarnayasotsset.html

O’Sullivan G. (2019) The 9 Types of Social Media Content You Need to Use, https://www.postplanner.com/blog/types-ofsocial-media-content

Opinion Poll in Kazakhstan: "Advertising Effectiveness and Popular Social Networks in the Republic of Kazakhstan". Retrieved from Elim Institute of marketing and sociological researches website: http://www.marketingcenter.kz/2018/0101-opros-socseti.html

Park N., Kee K.F., Valenzuela S. (2009) Being immersed in social networking environment: Facebook groups, uses and gratifications, and social outcomes. CyberPsychology \& Behavior, vol. 12(6), pp. 729-733.

Podsakoff P., Organ D. (1986) Self-reports in organizational research: problems and prospects. Journal of Management, vol. 12(1), pp. 69-82. 
Quan-Haase A., Young A.L. (2010) Uses and gratifications of social media: A comparison of Facebook and Instant Messaging'. Bulletin of Science, Technology \& Society, vol. 30(5), pp. 350-361.

Ramaswamy V., Ozcan K. (2016) Brand value co-creation in a digitalized world: An integrative framework and research implications. International Journal of Research in Marketing, vol. 33(1), pp. 93-106.

Reisinger Y., Turner L. (1999) A cultural analysis of Japanese tourists: challenges for tourism marketers. European Journal of Marketing, vol. 33(11/12), pp. 1203-1227.

Ridings C.M., Gefen D. (2004) Virtual community attraction: Why people hang out online. Journal of Computer-Mediated Communication, vol. 10(1).

Ruggiero T.E. (2000) Uses and gratifications theory in the 21st century. Mass Communication and Society, vol. 3(1), pp. 3-37.

Russ G.S., Daft R.L., Lengel R.H. (1990) Media selection and managerial characteristics in organizational communications. Management Communication Quarterly, vol. 4(2), pp. 151-175.

Sarma A. (2018) 5 types of social media content that convert, https://www.socialmediatoday.com/news/5-types-of-social-media-content-that-convert/539584/

See-To E.W.K., Ho K.K.W. (2014) Value co-creation and purchase intention in social network sites: The role of electronic word-of-mouth and trust - A theoretical analysis. Computers in Human Behavior, vol. 31, pp. 182-189.

Singaraju S.P., Nguyen Q.A., Niininen O., Sullivan-Mort G. (2016) Social media and value co-creation in multi-stakeholder systems: A resource integration approach. Industrial Marketing Management, vol. 54, pp. 44-55.

Taylor S., Todd P.A. (1995) Understanding information technology usage: A test of competing models. Information Systems Research, vol. 6(2), pp. 144-176.

Tenenhaus M., Vinzi V.E., Chatelin Y., Lauro C. (2005) PLS path modeling. Computational Statistics and Data Analysis, vol. 48, pp. 159-205.

Vinzi V.E., Trinchera L., Amato S. (2010) PLS path modeling: from foundations to recent developments and open issues for model assessment and improvement. In V. E. Vinzi, W. Chin, J. Henseler, \& H. Wang (Eds.), Handbook of partial least squares (pp. 47-82). Heidelberg: Springer.

Weick K.E. (1979) The social psychology of organizing ( $2^{\text {nd }}$ ed.). Paperback: 294 pages Publisher: McGraw-Hill, Management 2015/2(18), pp. 189-193.

Whiting A., Williams D. (2013) Why people use social media: A uses and gratifications approach. Qualitative Market Research: An International Journal, vol. 16(4), pp. 362-369.

Xu C., Ryan S., Prybutok V., Wen C. (2012) It is not for fun: An examination of social network site usage. Faculty Research \& Creative Activity, vol. 7. 